\title{
DESIGN OF PEOPLE EVACUATION FROM ROOMS AND BUILDINGS
}

\author{
Vytautas Papinigis $^{1}$, Edgaras Geda ${ }^{2}$, Kęstutis Lukošius ${ }^{3}$ \\ ${ }^{1}$ Department of Reinforced Concrete and Masonry Structures, Vilnius Gediminas Technical University, \\ Sauletekio al. 11, LT-10223 Vilnius, Lithuania, \\ ${ }^{2}$ Head of Prevention Division, State Fire Supervision Board, Fire and Rescue Department under the Ministry \\ of the Interior of the Republic of Lithuania, Švitrigailos g. 18, LT-03223 Vilnius, Lithuania \\ Department of Bridges and Special Structures, Vilnius Gediminas Technical University, \\ Sauletekio al. 11, LT-10223 Vilnius, Lithuania \\ ${ }^{3}$ Department of Labour and Fire safety, Vilnius Gediminas Technical University, \\ Saulètekio al. 11, LT-10223 Vilnius, Lithuania \\ E-mails: ${ }^{1} v y t a s @ p r o e x . l t ;{ }^{2}$ e.geda@vpgt.lt; ${ }^{3}$ k.lukosius@gmail.com \\ Received 21 May 2009; accepted 18 Jan. 2010
}

\begin{abstract}
There is a fire hazard in many civil buildings or engineering structures. Analysis of people evacuation time from the room or building is an important part of the designing process. Nevertheless, analysis of human behaviour in fire conditions is very complicated. Various factors should be evaluated, physical and even psychical, influencing safe evacuation of people from buildings. The analytical and calculating methods created are intended for analysis of people evacuation in fire conditions. Unfortunately, use of complicated calculations for determination of people evacuation requires too many resources; therefore, their application is limited. The calculation method for people evacuation presented in this paper is based on dependencies of the physical characteristics of people stream (density, intensity, movement speed) on people movement manner. The time required to evacuate people from people gathering room and building is determined in the numerical illustration of the method application. The article presents the comparison of simple calculation method and modeling with FDS+Evac software results of time for safe evacuation of people from rooms and buildings.
\end{abstract}

Keywords: people evacuation, safety, evacuation time, FDS+Evac.

\section{Introduction}

One of the most important conditions in view of implementation of the essential requirement for fire safety of a building is safe evacuation of people from buildings in fire conditions. Seeking to harmonize the principles of fire safety engineering, now the European Standards Committee (CEN) is actively working additionally to the International Standards Organization (ISO). The goal is to summarize experience of fires in buildings and people rescue operations, and to define efficient and reliable strategy for people safety. The Eurocodes are applied as guideline documents for the following purposes: as means to show that buildings and engineering structures meet the essential requirements of the Directive $89 / 106 / \mathrm{EEB}$, in particular, the essential requirement No. 1 Mechanical resistance and stability and the essential requirement No. 2 Fire safety; as background to prepare contracts for building works and related engineering services; as background to prepare harmonized technical requirements for building products.

The general aim of the construction product directive is to ensure the movement liberty of construction products and it takes a wide range of possibilities to assess the more precise fire resistance (Geda et al. 2004; Gribniak et al. 2006; Jonaitis and Papinigis 2006;
Blaževičius and Kvedaras 2007; Geda et al. 2007). Unfortunately there are not any recommendations or guides to assess the egress conditions and time that directly influence the design process.

During the last decade, pedestrian flow and evacuation have attracted the attention of researchers, and methods of physics and modern computer science have been successfully used to study the problem. Egress modelling is one of the important means of egress investigation (Isobe 1992; Muramatsu et al. 1999; Burstedde et al. 2001; Tajima and Nagatani 2001; Kirchner and Schadschneider 2002; Nagatani and Nagai 2004; Kuligowski 2005; Nagai et al. 2005; Nakayama et al. 2005; Qiu et al. 2005; Weng et al. 2006; Yang et al. 2006; Pelechano and Malkawi 2008; Tavares 2008). As typical models in evacuation modeling, the social force model (Helbing and Molnar 1995) and the discrete model (Isobe 1992), including lattice gas model and cellular automata model, are able to successfully simulate some typical phenomena observed in pedestrian dynamics. Recently, some experimental results have also been presented to validate the models of pedestrian flow and evacuation.

In reality, for the last few decades, as mentioned before, the evacuation models have been used to address fire safety issues within complex structures, where the prescriptive codes, generally, do not provide clear guid- 
ance. For this reason, these models have been largely applied for estimating the RSET (Required Safe Egress Time), instead of the use of hand calculations approach. Fahy (2002) also agrees with this statement, when she says that evacuation models are important tools for the evaluation of engineered designs, because such evaluations require the estimate of safe egress time for the occupants. In other terms, it could be said that there are essentially two methods available for calculating evacuation time, the more traditional hand calculation approach and with the use of evacuation models. The estimation of the evacuation time by using the hand calculation approach often follows the equations provided in the Society of Fire Protection Engineers (SFPE) Handbook (2002). Although it is possible to get a good indication of the total evacuation time in relatively low populated enclosed environments by using the hand calculation approach, the introduction of significant areas of congestion in highly populated buildings and structures means that a more appropriate method of calculation is to use one of the many evacuation models available. Therefore, evacuation models became useful tools within the FSE community. Furthermore, evacuation models have been developed largely over the last few decades. They are being used in a wide field of applications, such as crowd dynamics in open spaces, pedestrian movement in assemblies, human behaviour in evacuation process (i.e., commonly called also as egress process) during emergency situations in enclosed environments, etc. (and beyond the FSE community, evacuation models have been the object of study in many other fields of knowledge such as Risks Assessment/Safety Sciences, Crowd Management, Operation Research, Artificial Intelligence/ Computer Modelling, and many others (Nagai et al. 2005; Vaidogas and Juocevičius 2008, 2009; Zavadskas and Vaidogas 2009). Therefore, evacuation models became important sources for the understanding of evacuation processes in general. Nowadays, there are over 40 evacuation models. They can be used for different types of enclosed environments, such as: buildings, aircraft, ships and trains. For instance, Pelechano and Malkawi (2008) present an interesting work discussing the use of evacuation models for simulation of evacuation processes in high- rise building.

The new one direction of the evacuation models assesses the influence of the fire thermal and toxic actions. Usually the mentioned actions are determined according to advanced fire simulation methods (Galaj 2009; Chow and Chow 2009) and also combustion of materials models (Polka 2008; Konecki and Polka 2009).

All of these models have their advantages and disadvantages. But, in general terms, what makes them different from each other is the way they represent the geometry of the structure, the occupant's characteristics, etc. And besides that, the manner that their inherent algorithms work, will determine how accurate the evacuation model is. In the literature, there are a few evacuation models' reviews. Friedman (1992) can be mentioned as the "pioneer'" of such kind of reviews. Olenick and Carpenter (2003) have updated this survey. Their work is internationally well known and available. Therefore, it is not the objective of this paper to analyse in depth evacuation models. In the next section, the concepts of safe design in terms of evacuation processes efficiency are discussed.

We can apply the calculation and normative methods for evaluation of people evacuation. The calculation methods may be further conditionally subdivided into simple and complicated ones; the latter is used mostly in the special applied software (Fahy 2002).

With proliferation of computers and development of information technologies in the field of fire engineering for people evacuation calculations, we now are able to use different applied software. The most popular examples of such software are: FDS+Evac, FPETool, EVACNET4, TIMTEX, WAYOUT, STEPS, PedGo, PEDROUTE/PAXPORT, Simulex, GridStream, ASERI, buildingEXODUS, EXITT, Legion, etc. (Helbing et al. 2005). This software enables us to simulate and evaluate very complex factors influencing people evacuation: people counter-stream, blocking of exits, influence of fire scenario on human behaviour, to divide people into target groups, to forecast behaviour of handicapped persons, to evaluate people evacuation delay because of message authenticity confirmation and preparations for evacuation, use of lifts, impact of toxic combustion products, individual resources of personal physical endurance, selection of evacuation directions, distribution of visitors in the room, etc. Such software is used to simulate people movement both in cases of fires or other accidents and in investigations of people movement streams when implementing functional requirements for the building, e.g., well-balanced distribution of people streams in supermarkets, railway stations, airports, stadiums, etc. Information obtained can serve to the building engineer as the cognitive guideline, which may be used in a case of impossibility to meet people evacuation requirements of the normative technical documents of building industry. The above-mentioned software enables also to analyse and adjust people evacuation assumptions made in normative documents according to the features of the particular building and persons being in it.

FDS+Evac program was developed at VTT Technical Research Centre of Finland to simulate human egress. The program allowed to setup the different properties and escape strategies for each agent. The resulting equations of motions for the movement and rotational degrees of freedom are solved using the methods of dissipative particle dynamics. Thus, the model uses continuous time and space to track the trajectories of the agents. FDS+Evac allows the modelling of high crowd density situations and the interaction between evacuation simulations and fire simulations. Some social interactions among the agents are introduced in the model. A reaction function model is used to select the emergency exits.

In the next section, the concepts, which are the background of Lithuanian building codes statements of evacuation, are discussed and comparison of simple calculation method and modelling with FDS+Evac software results of time for safe evacuation of people from rooms and buildings is given. 


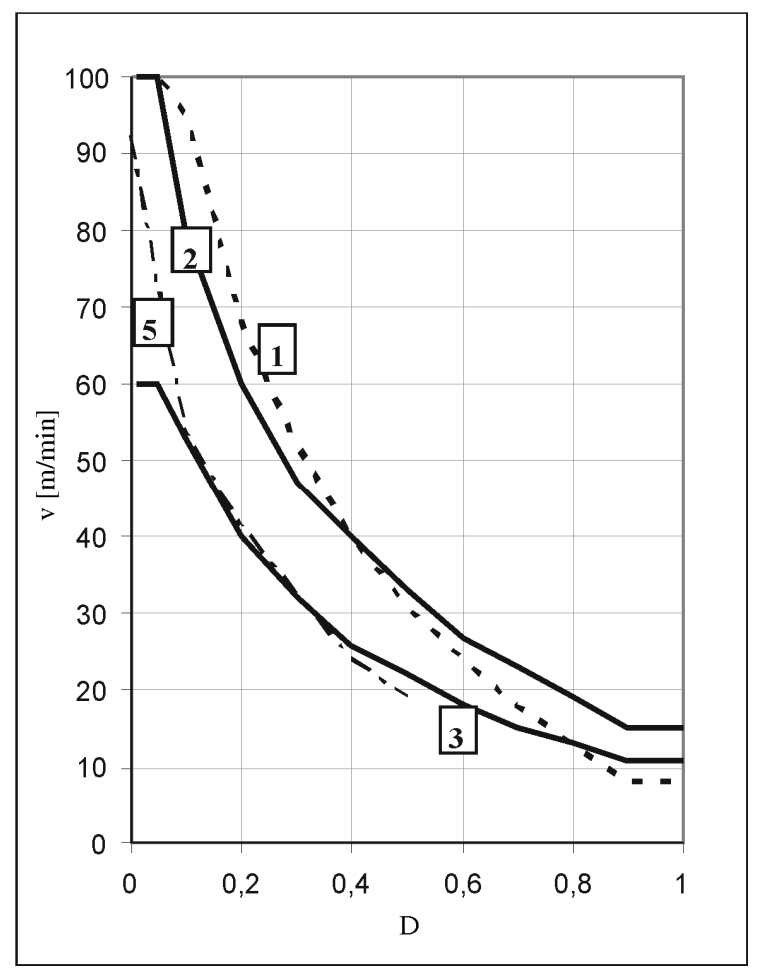

a)

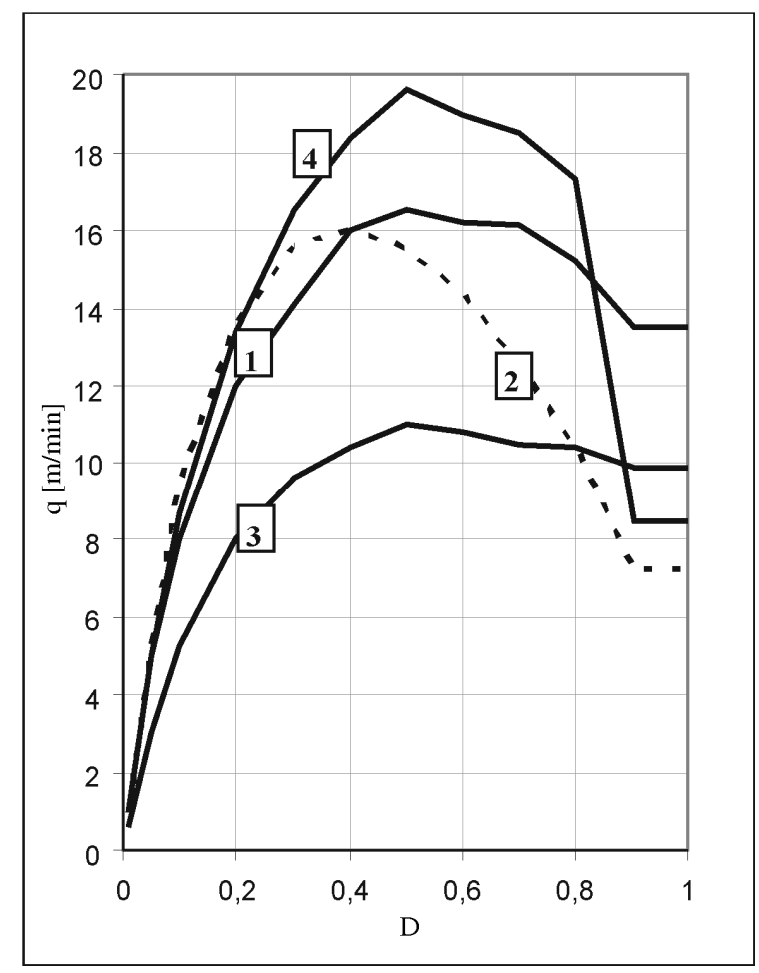

b)

Fig. 1. People movement speed versus evacuation stream type and density: 1 - horizontal movement; 2 - down; 3 - up; 4 - through openings and doors, 5 - FDS+Evac

\section{Calculation principle}

The normative method to evaluate people evacuation is based on verification of compliance of requirements to the people evacuation routes and exits. This method is the most popular because of its application simplicity and should be applied in all typical cases. Nevertheless, when applying this method, the engineer usually fails to obtain the special knowledge required to understand essential factors influencing people evacuation and the margins provided in the normative method.

This paper presents the example of simple calculation for people evacuation from the theatre hall with chair rows, because the normative technical documents of building industry regulate only evacuation time for halls with chair rows with no hint on its determination. When calculating the people evacuation time, the following two conditions are verified separately (Предтеченский and Милинский 1979):

$$
\begin{gathered}
\tau_{\text {calc.route }}=\frac{l}{v} \leq \tau_{\text {allowable }}, \\
\tau_{\text {calc. exit }}=\frac{N}{q_{\text {door }} \delta} \leq \tau_{\text {allowable }},
\end{gathered}
$$

where: $\tau_{\text {calc.route }}$ - calculated people evacuation time determined by the length of evacuation route, min.; $l-$ length of evacuation route, $\mathrm{m} ; \mathrm{v}$ - speed of people stream movement, $\mathrm{m} / \mathrm{min}$; $\tau_{\text {calc.exit }}$ - calculated people evacuation time determined by throughput of evacuation passages, min.; $N$ - number of persons evacuated through the exits; $q_{\text {door }}$ - calculated relative door throughput, persons $/(\mathrm{m} \cdot \mathrm{min}$.$) , generally taken as 87$ persons/(m·min.); $\delta$ - width of the evacuation exit, $\mathrm{m}$.

It is essential to understand the following main characteristics of the people evacuation stream density $D$ and intensity $q$. Depending on calculation type, there are distinguished three types of people evacuation stream density: absolute $D_{a b s}$, persons $/ \mathrm{m}^{2}$, relative $D_{\text {relat }}$, $\mathrm{m}^{2} / \mathrm{m}^{2}$, and linear $D_{\text {lin }}, \mathrm{m} /$ person (Ройтман 1985). The people evacuation stream intensity $q$ is the number of persons, passing through $1 \mathrm{~m}$ of width of evacuation passage or exit in one minute. The people stream movement intensity can also be absolute $q_{a b s}$, persons/(m·min.) and relative $q_{\text {relat }}, \mathrm{m} / \mathrm{min}$. When the relative values of density $D_{\text {relat }}$ and intensity $q_{\text {relat }}$ are multiplied by 10 , the absolute values $D_{a b s}, q_{a b s}$ are obtained.

The people evacuation stream characteristics $q_{\text {relat }}$, $D_{\text {relat }}$ and $v$ are determined in the diagram of Fig. 1 or Table 1.

People movement in the theatre hall is divided into stages by movement intensity. There are two movement stages distinguished in the theatre halls - in chair rows and in passages. Movement density in chair rows is taken as $D=0,5 \mathrm{~m} /$ person or $D=4 \div 5$ persons $/ \mathrm{m}^{2}$, and people movement characteristics in passages are taken as limit value. Taking into account assumptions made earlier, we 
Table 1. People stream speed and intensity versus density

\begin{tabular}{c|c|c|c|c|c|c|c}
\hline \multirow{2}{*}{$\begin{array}{c}\text { People stream density } \\
\mathrm{D}, \text { persons/m }\end{array}$} & \multicolumn{2}{|c|}{ Horizontal distance } & Door opening & \multicolumn{2}{|c|}{ Stairs down } & \multicolumn{2}{c}{ Stairs up } \\
\cline { 2 - 9 } & $\begin{array}{c}\text { Speed } v, \\
\mathrm{~m} / \mathrm{min} .\end{array}$ & $\begin{array}{c}\text { Intensity } \\
q, \mathrm{~m} / \mathrm{min} .\end{array}$ & $\begin{array}{c}\text { Intensity } q, \\
\mathrm{~m} / \mathrm{min} .\end{array}$ & $\begin{array}{c}\text { Speed } v, \\
\mathrm{~m} / \mathrm{min} .\end{array}$ & $\begin{array}{c}\text { Intensity } \\
q, \mathrm{~m} / \mathrm{min} .\end{array}$ & $\begin{array}{c}\text { Speed } v, \\
\mathrm{~m} / \mathrm{min} .\end{array}$ & $\begin{array}{c}\text { Intensity } q, \\
\mathrm{~m} / \mathrm{min} .\end{array}$ \\
\hline 0,01 & 100 & 1 & 1 & 100 & 1 & 60 & 0,6 \\
\hline 0,05 & 100 & 5 & 5 & 100 & 5 & 60 & 3 \\
\hline 0,1 & 80 & 8 & 8.7 & 95 & 9.5 & 53 & 5.3 \\
\hline 0,2 & 60 & 12 & 13.4 & 68 & 13.6 & 40 & 8 \\
\hline 0,3 & 47 & 14.1 & 16.5 & 52 & 15.6 & 32 & 9.6 \\
\hline 0,4 & 40 & 16 & 18.4 & 40 & 16 & 26 & 10.4 \\
\hline 0,5 & 33 & 16.5 & 19.6 & 31 & 15.5 & 22 & 11 \\
\hline 0,6 & 27 & 16.2 & 19 & 24 & 14.4 & 18 & 10.8 \\
\hline 0,7 & 23 & 16.1 & 18.5 & 18 & 12.6 & 15 & 10.5 \\
\hline 0,8 & 19 & 15.2 & 17.3 & 13 & 10.4 & 13 & 10.4 \\
\hline$\geq 0,9$ & 15 & 13.5 & 8.5 & 8 & 7.2 & 11 & 9.9 \\
\hline
\end{tabular}

assume the people movement speed in chair rows is $v_{1}^{\prime}$, and that in passages between rows is $v_{2}^{\prime}$. Then the evacuation time from the hall for the maximal distance is determined by the equation:

$$
\tau_{\text {hall }}^{\prime}=\frac{\mathbf{l}_{1}^{\prime}}{v_{1}^{\prime}}+\frac{\mathbf{l}_{2}^{\prime}}{v_{2}^{\prime}} \leq \tau_{\text {allowable }}^{\prime},
$$

where: $l_{1}^{\prime}$ - maximal distance from the farthest spectator place to the nearest passage in the chair row, $\mathrm{m} ; \mathrm{l}_{2}^{\prime}-$ maximal distance from the farthest row to the nearest exit from the hall, $\mathrm{m} ; v_{1}^{\prime}$ - people movement speed in the chair row, $\mathrm{m} / \mathrm{min}$; $v_{2}^{\prime}$ - people movement speed in the passages between chair rows, $\mathrm{m} / \mathrm{min}$.

This equation is valid only in a case, when exit doors are located symmetrically in the hall and each exit opening receives that same number of persons. In other cases, each exit door is verified separately, depending on its throughput and location.

Results of investigation carried out by Prof. Predtechenskiy (Предтеченский, Милинский 1979) have disclosed that people streams in theatre halls with chair rows are distributed rather typically, so he has proposed to apply for calculations the following characteristics of people stream movement speed: $\mathrm{v}_{1}=40 \mathrm{~m} / \mathrm{min}$. and $\mathrm{v}_{2}=16 \mathrm{~m} / \mathrm{min}$.

When the length of the chair row, $1_{1}^{\prime}$, is known, the maximal allowed distance of passage between rows, $i_{2}^{\prime}$, may be determined by the following equation, taking into account that the evacuation time shall not exceed the normative evacuation time $\tau_{\text {sale }}$ from the hall:

$$
\mathbf{l}_{2}^{\prime}=\left(\tau_{\text {hall }}^{\prime}-\frac{\mathbf{l}_{1}^{\prime}}{v_{1}^{\prime}}\right) v_{2}^{\prime} \text {. }
$$

The evacuation time at the exit through the door for given door throughput is determined by the equation:

$$
\tau_{\text {door }}=\frac{N}{Q} \leq \tau_{\text {hall }}^{\prime},
$$

where: $\mathrm{N}$ - number of persons evacuated through the door; $\mathrm{Q}$ - door throughput, persons/min.

The door throughput is determined by the equation:

$$
Q=\sum \delta \cdot q_{\text {door }}
$$

where: $\Sigma \delta$ - width of the door, passage, m; $q_{\text {door }}-$ calculated relative door throughput, persons/(m·min.), generally taken as 87 persons $/(\mathrm{m} \cdot \mathrm{min}$.).

Evacuation time for given door throughput from the hall is determined by the equation:

$$
\tau_{\text {hall }}^{\prime}=\frac{N}{\sum \delta \cdot q_{\text {duru }}} \leq \tau_{\text {allowable }}^{\prime} .
$$

In a case when evacuation through the door starts after some delay (when the exit is at some distance from the nearest spectator places), the previous equation is rewritten as:

$$
\tau_{\text {hall }}^{\prime}=\frac{N}{\sum \delta \cdot q_{\text {door }}} \leq \tau_{\text {allowable }}^{\prime}-\tau_{\text {initial }}^{\prime},
$$

where: $\tau_{\text {initial }}^{\prime}$ - time lap (delay) before evacuation through the door, exit, min.

The width of evacuation door in the hall, taking into account the allowed evacuation time $\tau_{\text {allowable }}^{\prime}$, is determined by the equation:

$$
\sum \delta_{\text {req }}=\frac{N}{q_{\text {door }} \cdot \tau_{\text {allowable }}^{\prime}} .
$$

The number of persons leaving the hall in the allowed evacuation time $\tau_{\text {allowable }}^{\prime}$ is determined by the equation:

$$
N=\sum \delta \cdot q_{\text {door }} \cdot \tau_{\text {allowable }}^{\prime}
$$

The width of passages between (across) the rows is taken not less than the necessary width of evacuation door. So the most favourable evacuation conditions are created. When determining the width of passages between chair rows it is necessary to assure that the corresponding area could contain the whole calculated number of persons from the chair row.

Determination of passage width for given passage capacity is called the "volume method". The main safety requirement may be expressed as: 


$$
a N \leq D \cdot F+\Delta N,
$$

where: $\mathrm{N}$ - number of chairs in one row, persons from which are entering the passage under discussion; a number of rows in a chair group; $\mathrm{F}$ - passage area for chair group under discussion, $\mathrm{m}^{2} ; \Delta \mathrm{N}-$ number of persons having left the passage before separate streams (from chair rows) fill the passage up to the door.

This gives:

$$
\begin{gathered}
\Delta N=q_{\text {door }} \cdot \delta_{\text {door }} \cdot \tau, \\
F=\delta_{\text {passage }} \cdot l, \\
\tau=\frac{l_{1}^{\prime}}{v_{1}^{\prime}},
\end{gathered}
$$

where: $\tau-$ time to fill the passage with separate streams (from rows), min.; $\delta_{\text {door }}-$ width of the door serving this passage, $\mathrm{m} ; \delta_{\text {passage }}$ - passage width, $\mathrm{m}$.

By rearranging the above expressions, we obtain the following equation:

$$
a N=D \cdot \delta_{\text {passage }} \cdot l+q \cdot \delta_{\text {door }} \cdot \frac{l_{1}^{\prime}}{v_{1}^{\prime}},
$$

which gives:

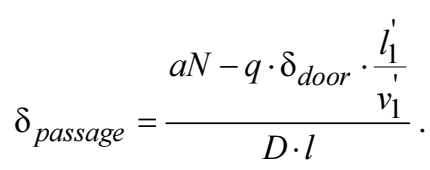

Assuming that the width of the passage between the rows is constant, we can obtain the number of chairs in the row:

$$
N=\frac{D \cdot \delta_{\text {passage }} \cdot l+q \cdot \delta_{\text {door }} \cdot \frac{l_{1}^{\prime}}{v_{1}^{\prime}}}{a} .
$$

These calculations give the following conclusion: when the number of chairs in the row is 20 and the number of rows is 18 , then, having the door width equal to $1.5 \mathrm{~m}$ and $D_{\mathrm{F}}=12$ persons $/ \mathrm{m}^{2}$, we obtain the width of the passage to the door equal to $1.8 \mathrm{~m}$. When the door width is increased and number of rows is decreased, the passage width diminishes.

Outside theatre hall boundaries, the people evacuation time is calculated using the expressions presented below:

$$
D=\frac{N \cdot f}{l \cdot \delta}
$$

where: $D$ - people stream density, $\mathrm{m} / \mathrm{min}$.; $N$ - number of persons; $f$ - average horizontal projection of a person, $\mathrm{m}^{2}$ (taken as 0.125$) ; l, \delta$ - length and width of the room or passage, or area of the room or passage, $\mathrm{m}^{2}$.

$$
q_{i}=\frac{q_{i-1} \cdot \delta_{i-1}}{\delta_{i}},
$$

where: $q_{i}, q_{i-1}$ - people movement intensity in appropriate stages, $\mathrm{m} / \mathrm{min} . ; \delta_{i}, \delta_{i-1}-$ width of evacuation passages in appropriate stages, $\mathrm{m}$.
When several evacuation streams merge into one, we have:

$$
q_{i}=\frac{\sum q_{i-1} \cdot \delta_{i-1}}{\delta_{i}} .
$$

Evacuation time is determined by the equation:

$$
\tau_{i}=\frac{l_{i}}{v_{i}}
$$

where: $\tau_{i}$ - people evacuation time, min.; $l_{i}$ - length of the evacuation passage, $\mathrm{m} ; v_{i}$ - movement speed in the evacuation passage, $\mathrm{m} / \mathrm{min}$.

Dispersion time for people jam at the exit opening (door) is determined by the equation:

$$
\Delta \tau=N_{i} \cdot f\left[\frac{1}{q_{\text {door }} \cdot \delta_{\text {door }}}-\frac{1}{\sum\left(q_{i-1} \cdot \delta_{i-1}\right)}\right],
$$

where $\Delta \tau$ - dispersion time for people jam at the exit opening (door), min.; $q_{\text {door }}$ - people movement intensity through the door, $\mathrm{m} / \mathrm{min}$; $q_{i-1}$ - people stream movement intensity before the door, $\mathrm{m} / \mathrm{min}$;; $\delta_{\text {door }}-$ width of the evacuation door, $\mathrm{m} ; \delta_{i-1}$ - width of the evacuation passages before the doors, $\mathrm{m}$. staircase:

The time needed for all the persons to escape to the

$$
\tau_{\text {staircase }}=\tau_{\text {before staircase }}+\frac{N}{\delta \cdot q},
$$

where: $\tau_{\text {staircase }}-$ time needed for all the persons being evacuated to escape to the staircase, min.; $\tau_{\text {before staircase }}$ time for evacuation up to the staircase, min.; $N$ - number of persons being evacuated through the staircase; $\delta-$ width of the door to the staircase, $\mathrm{m} ; \quad q$ - people movement intensity through the door, persons/(m·min.).

Experience in designing the buildings for people gatherings witnesses that dimensions of corridors, lobbies and other rooms are chosen so as to have $4 \div 5$ persons per $1 \mathrm{~m}^{2}\left(0.2 \div 0.25 \mathrm{~m}^{2} /\right.$ person $)$ in time of evacuation. Considering the fact that the stream intensity in the abovementioned rooms in time of compulsory evacuation can be greater, the people movement speed is taken not more than $24 \mathrm{~m} / \mathrm{min}$. This speed may be taken when calculating the time to reach the staircase or outer door. People stream density in lobbies is usually much greater than that in corridors, and reaches up to $8 \div 12$ persons $/ \mathrm{m}^{2}$. Therefore, the movement speed between the staircase and the outer door should be taken according to the maximal density value, i.e. $v=16 \mathrm{~m} / \mathrm{min}$. The people movement speed on the staircases of the people gathering buildings is always taken not greater than $10 \mathrm{~m} / \mathrm{min}$. Door throughput in the people gathering buildings is always taken as the limit value.

In FDS+Evac Humans are modelled as agents, which are moving in a $2 \mathrm{D}$ geometry representing the floors of buildings. The method of Helbing's (1995) group is used as the starting point of the agent movement algorithm of FDS+Evac, where the so-called "social force" is introduced to keep reasonable distances to walls 
and other agents.FDS+Evac uses the laws of mechanics to follow the trajectories of the agents during the calculation. Each agent follows its own equation of motion:

$$
m_{i} \frac{d^{2} x_{i}(t)}{d t^{2}}=f_{i}(t)+\xi_{i}(t),
$$

where $x_{i}(t)$ is the position of the agent $i$ at time $t, f_{i}(t)$ is the force exerted on the agent by the surroundings, $m_{i}$ is the mass, and $\xi_{i}(t)$ is a small random fluctuation force.

The force on the agent $i$ has many components:

$$
\begin{aligned}
& f_{i}=\frac{m_{i}}{t_{i}}\left(v_{i}^{0}-v_{i}\right)+ \\
& \sum_{j \neq i}\left(f_{i j}^{s o c}+f_{i j}^{c}+f_{i j}^{a t t}\right)+ \\
& \sum_{w}\left(f_{i w}^{s o c}+f_{i w}^{c}\right)+\sum_{k} f_{i k}^{a t t},
\end{aligned}
$$

where the sum over $j \neq i$ describes agent-agent interactions, the sum over $w$ describes agent-wall interactions, and the sum over $k$ describes agent-environment interactions, like the fire-agent repulsion. The value $f_{i}$ describes the motive force on the evacuating agent. Each agent tries to walk at its own specific walking speed towards an exit or some other target, whose direction is given by the direction of the field $v_{i}^{0}$. The relaxation time parameter $t_{i}$ sets the strength of the motive force, which makes an agent to accelerate towards the preferred walking speed.

The calculation has been made as "fire drill" situation to compare the results by two different calculation methods. It means that no fire was modelled in the hall and the lobby to have less factors influencing the calculation results and more closer to the simplified calculation method.

All the agents have had "adult" properties. The comparison of human properties used in two different methods is presented in Table 2 .

Table 2. The summary of a human average horizontal projection and unimpeded moving speed used in simplified and FDS+Evac methods

\begin{tabular}{l|c|c|c|c}
\hline \multirow{2}{*}{ Description } & \multicolumn{2}{|c|}{$\begin{array}{c}\text { Average horizontal } \\
\text { projection of } \\
\text { a person, }\end{array}$} & \multicolumn{2}{c}{$\begin{array}{c}\text { Unimpeded moving } \\
\text { speed, m/s }\end{array}$} \\
\cline { 2 - 5 } & $\begin{array}{c}\text { Simplified } \\
\text { method }\end{array}$ & $\begin{array}{c}\text { FDS+ } \\
\text { Evac }\end{array}$ & $\begin{array}{c}\text { Simplified } \\
\text { method }\end{array}$ & $\begin{array}{c}\text { FDS+ } \\
\text { Evac }\end{array}$ \\
\hline Adult & 0.1 & $0.120^{*}$ & 1.66 & 1.25 \\
\hline Male & 0.1 & 0.136 & 1.66 & 1.35 \\
\hline Female & 0.1 & 0.106 & 1.66 & 1.15 \\
\hline Child & 0.07 & 0.079 & 1.66 & 0.9 \\
\hline Elderly & 0.1 & 0.118 & 1.66 & 0.8 \\
\hline $\begin{array}{l}\text { Adult } \\
\text { (winter cloths) }\end{array}$ & $0.125^{*}$ & - & 1.66 & 1.25 \\
\hline
\end{tabular}

* - values used in calculation

\section{Calculations of buildings and rooms}

Project Statement. The theatre hall has 200 chairs, length of the passage between rows is $15 \mathrm{~m}$, distance from the farthest row to the nearest evacuation exit is $10 \mathrm{~m}$, width of the passage between rows is $2 \mathrm{~m}$, there are two doors between the hall and the lobby having the width of $1.5 \mathrm{~m}$ each, normative evacuation (from the hall) time is $2 \mathrm{~min}$., the lobby (outside hall boundaries) has length of $20 \mathrm{~m}$ and width of $2 \mathrm{~m}$, width of evacuation doors to the yard is $1.5 \mathrm{~m}$. It is needed to determine people evacuation time from the hall and from the building (see Fig. 2).

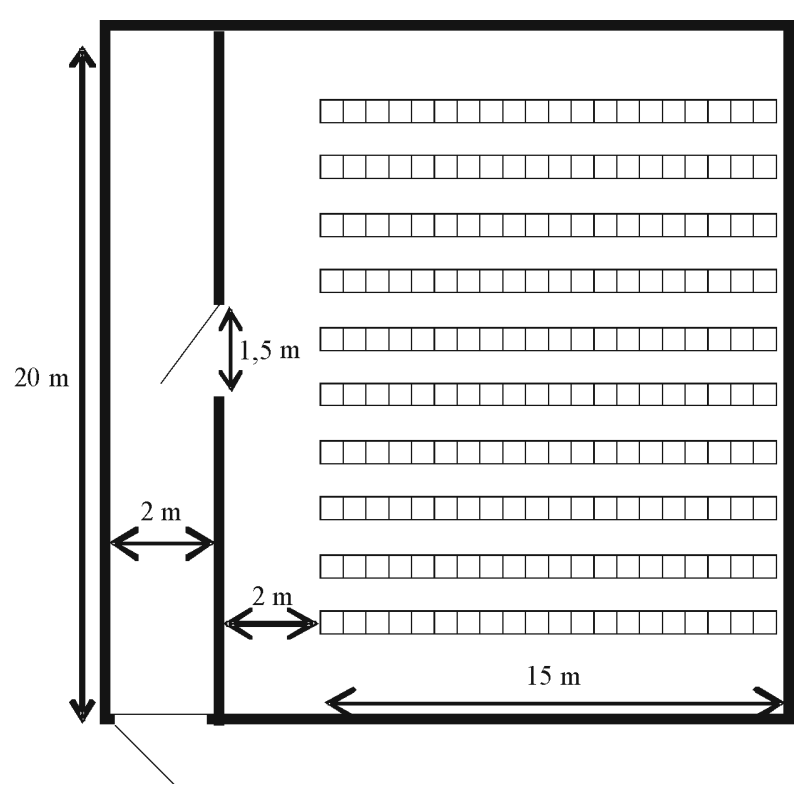

Fig. 2. The plan of the theatre hall and lobby.

FDS+Evac program and simplified method were used to estimate the egress time from the theatre hall. The hall capacity was 200 humans distributed in 10 rows with 20 chairs. The distance between the chair rows is $0.75 \mathrm{~m}$ and the chair depth is $0.5 \mathrm{~m}$. The passage width that is from the three sides of the sitting area is $2 \mathrm{~m}$. There is one emergency exit of $1.5 \mathrm{~m}$ in width from the hall that is well known for the people because they have passed to the hall through the same door. The evacuation starts when the people are in their places.

At first, we have to say that calculation methods used have essentially different calculation strategies and approaches. But on the other side, the similar properties are influenced by the calculation results. For more detailed result analysis we have divided the whole egress into two general parts: egress from the hall and egress from the lobby. The comparison of the egress times is given in Table 3 and Fig. 3.

The people jam at the exit opening (door) fate at the time of first stage of evacuation from the theatre hall. The evacuation time from the theatre rows varies from $18 \mathrm{~s}$ ( $10^{\text {th }}$ row) to $70 \mathrm{~s}$ ( $5^{\text {th }}$ row) and walking speed is from $0.21 \mathrm{~m} / \mathrm{s}$ to $0.83 \mathrm{~m} / \mathrm{s}$ respectively. The result could be explained that the $10^{\text {th }}$ row end is in optimal distance from the exit (it is near the $8^{\text {th }}$ row) as the people jam reason and the people jam centre that is near the $5^{\text {th }}$ row. 
Table 3. The comparison of the egress times according to simplified and FDS+Evac methods

\begin{tabular}{l|c|c|c}
\hline $\begin{array}{c}\text { Evacuation } \\
\text { from }\end{array}$ & $\begin{array}{c}\text { Simplified } \\
\text { method egress } \\
\text { time, } \mathrm{s}\end{array}$ & $\begin{array}{c}\text { FDS+Evac } \\
\text { method egress } \\
\text { time, } \mathrm{s}\end{array}$ & $\begin{array}{c}\text { Deviation*, } \\
\%\end{array}$ \\
\hline Theatre hall & 138.8 & 87 & 59.54 \\
\hline Lobby & 13.2 & 20 & -34.00 \\
\hline Total (building) & 152 & 107 & 42.06 \\
\hline
\end{tabular}

* - the FDS+Evac method results were compared with simplified method of egress time.

And the people from the $5^{\text {th }}$ row are the last to leave because they are in the centre of the people jam. In simplified method according to conservative approach, people movement speed in the chair row is $0.666 \mathrm{~m} / \mathrm{s}$ and $0.266 \mathrm{~m} / \mathrm{s}$ in the passages between chair rows. These values are more conservative in comparison with maximum walking speed evaluated by the FDS+Evac model when there is no influence of the people jam. But the evacuation time from rows is not as important as the evacuation time from the theatre hall because the people could be affected by fire in the hall.

The people jam dispersion time directly depends on the exit door width that in our situation was $1.5 \mathrm{~m}$. The flow rate is used to determine the throughput of the door dependent on the width. In the FDS+Evac model by default value of the flow rate is 1.43 persons/s and in general depends on the social force anisotropy parameter value. The flow rate depends on the people stream density and the exit door width in the simplified method (see Fig. 1). In this case 1.41 persons/s value (for $1 \mathrm{~m}$ width of exit) of the flow rate was used (for $1.5 \mathrm{~m}$ exit it is 2.175 persons/s). The both used values are quite similar to each other and the throughput influence is less than $2 \mathrm{~s}$. We could conclude that quite a big difference between the evacuation times from the theatre hall according to different methods is the result of the walking speed differences in the calculation models and initial egress time from theatre hall. Simplified method uses linear conservative approach which means that evacuation through theatre door starts when the last man could come unto door. Therefore we have the main difference (45 s) in whole building evacuation time (see Table 3 and Fig. 3).

Another 34\% difference between the calculated egress times was in the lobby room. The reason of that are also differences in walking speed of humans in calculating methods. The properties of the second exit door were the same, but the walking speed of humans according to simplified method is $1.5 \mathrm{~m} / \mathrm{s}$ and FDS+Evac model uses $1.0 \mathrm{~m} / \mathrm{s}$ value. It has to be noted that maximum number of people in the lobby is different according to used methods. The FDS+Evac model output data inform that the maximum number in the lobby room was only 50 people, but according to this model the people walked more slowly than 200 people. According to simplified model the theatre door throughput is 2.175 people/s and evacuation time through lobby to outside of the building is $13.2 \mathrm{~s}$, while maximum number in the lobby room was only 28.71 people (see Table 3 and Fig. 3 ).

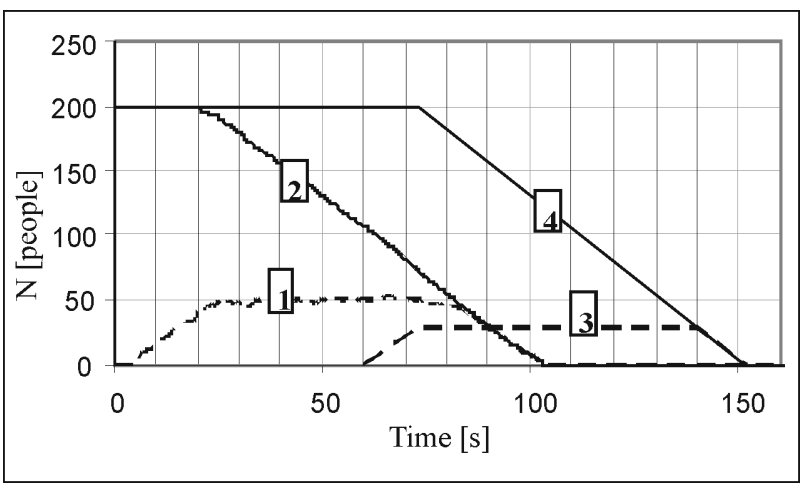

Fig. 3. Number of people versus evacuation time in building and lobby: 1 - lobby (FDS+Evac); 2 - building (FDS+Evac); 3 - lobby (simplified method); 4 - building (simplified method)

\section{Concluding remarks}

The people evacuation calculation model, based on the harmonized standard, and description of the main characteristics of the people evacuation stream, determining people safety in a case of fire, are presented in this paper.

The simple calculation method is presented which, in comparison with the complicated computer software, enables to determine efficiently the time for safe evacuation of people from rooms and buildings.

People evacuation time from the people gathering room and building is determined in the numerical illustration of the method application.

\section{References}

Bacinskas, D.; Kaklauskas, G.; Geda, E. 2004. FE Software ATENA Applications to Non-linear analysis of RC beams subjected to high temperatures, Journal of Civil Engineering and Management 10(Suppl. 1): 11-18.

Bačinskas, D.; Kaklauskas, G.; Gribniak, V.; Geda, E. 2007. Gelžbetoninių plokščiu, veikiamų gaisro poveikio, modeliavimas [The modelling of reinforced slabs exposed to fire], Technological and Economic Development of Economy 13(4): 295-302.

Blaževičius, Ž.; Kvedaras, A. K. 2007. Experimental investigation into fire resistance of HC-FST columns under axial compression, Journal of Civil Engineering and Management 13(1): 1-10.

Burstedde, C.; Klauck, K.; Schadschneider, A.; Zittartz, J. 2001. Simulation of pedestrian dynamics using a twodimensional cellular automaton, Physica A 295: 507-532. doi:10.1016/S0378-4371(01)00141-8

Chow, Ch. L.; Chow, W. K. 2009. Fire safety aspects of refuge floors in supertall buildings with computational fluid dynamics, Journal of Civil Engineering and Management 15(3): 225-236. doi:10.3846/1392-3730.2009.15.225-236

Fahy, R. F. 2002. Tools for the simulation of human behaviour, Fire Protection Engineering 16: 19-22.

Friedman, R. 1992. An international survey of computer models for fire and smoke, Journal of Fire Protection Engineering 4(3): 81-92. doi:10.1177/104239159200400301

Galaj, J. 2009. A general concept of fire hybrid modelling in compartments, Journal of Civil Engineering and Management 15(3): 237-245. doi:10.3846/1392-3730.2009.15.237-245 
Gribniak, V.; Bačinskas, D.; Kaklauskas, G. 2006. Numerical simulation strategy of reinforced concrete tunnel bearing members in fire, The Baltic Journal of Road and Bridge Engineering 1(1): 5-9.

Helbing, D.; Molnar, P. 1995. Social force model for pedestrian dynamics, Physical Review E 51: 4282-4288. doi:10.1103/PhysRevE.51.4282

Helbing, D.; Buzna, L.; Johansson, A.; Werner, T. 2005. Selforganized pedestrian crowd dynamics: experiments, simulations, and design solutions, Transportation Science 39: 1-24. doi:10.1287/trsc.1040.0108

Isobe, M.; Adachi, T.; Nagatani, T. 1992. Experiment and simulation of pedestrian counter flow, Journal of Fire Protection Engineering 4(3): 81-92.

ISO/TR 13387-8. Fire safety engineering. Part 8: Life safety. Occupant behaviour, location and condition. ISO, 2002. $36 \mathrm{p}$.

Jonaitis, B.; Papinigis, V. 2006. Nauja Europos sajungos gaisro temperatūrų veikiamų gelžbetoninių konstrukcijų projektavimo metodika. [New European Union design method of reinforced structures exposed to fire temperature], Technological and Economic Development of Economy 12(2): 108-117.

Kirchner, A.; Schadschneider, A. 2002. Simulation of evacuation processes using a bionics-inspired cellular automaton model for pedestrian dynamics, Physica A 312: 260-76. doi:10.1016/S0378-4371(02)00857-9

Kuligowski, E. D. 2005. A Review of Building Evacuation Models. Technical Note 1471. National Institute of Standards and Technology. $156 \mathrm{p}$.

Konecki, M.; Polka, M. 2009. Simple fire model for comparative studies of critical conditions during combustion of chosen polymer materials, Journal of Civil Engineering and Management 15(3): 247-257. doi:10.3846/1392-3730.2009.15.247-257

Muramatsu, M.; Irie, T.; Nagatani, T. 1999. Jamming transition in pedestrian counter flow, Physica A 267: 487-585. doi:10.1016/S0378-4371(99)00018-7

Nagai, R.; Fukamachi, M.; Nagatani, T. 2005. Experiment and simulation of counterflow of people going on all floors, Physica A 358: 516-544. doi:10.1016/j.physa.2005.04.024

Nagatani, T.; Nagai, R. 2004. Statistical characteristics of evacuation without visibility in random walk model, Physica A 341: 638-686. doi:10.1016/j.physa.2004.04.124

Nakayama, A.; Hasebe, K.; Sugiyama, Y. 2005. Instability of pedestrian flow and phase structure in a two-dimensional optimal velocity model, Physical Review E 71: 11-72. doi:10.1103/PhysRevE.71.036121

Olenick, S.; Carpenter, D. 2003. An updated international survey of computer models for fire and smoke, SFPE Journal of Fire Protection Engineering 13(2): 87-110. doi:10.1177/1042391503013002001
Pelechano, N.; Malkawi, A. 2008. Evacuation simulation models: challenges in modelling high rise building evacuation with cellular automata approaches, Automation in Construction 17(4): 377-462. doi:10.1016/j.autcon.2007.06.005

Polka, M. 2008. The influence of flame retardant additives on fire properties of epoxy materials, Journal of Civil Engineering and Management 14(1): 45-48. doi:10.3846/1392-3730.2008.14.45-48

Qiu, B.; Tan, H.; Zhang, C.; Kong, L.; Liu, M. 2005. Cellular automaton simulation of the escaping pedestrian flow in corridor, International Journal of Modern Physics C 16: 225-260. doi:10.1142/S0129183105007030

STR 2.01.04. Gaisrinè sauga. Pagrindiniai reikalavimai [Fire Safety. Main Requirements]. Vilnius, 2004. 34 p.

Tajima, Y.; Nagatani, T. 2001. Scaling behavior of crowd flow outside a hall, Physica A 292: 545-599. doi:10.1016/S0378-4371(00)00630-0

Tavares Rm. 2008. Evacuation processes versus evacuation models: "Quo Vadimus?", Fire Technology.

The SFPE handbook of fire protection engineering. 3rd ed. 2002. Bethesda, MD: Society of Fire Protection Engineers. 3367-3380.

Vaidogas, E. R.; Juocevicius, V. 2008. Sustainable development and major industrial accidents: the beneficial role of riskoriented structural engineering, Technological and Economic Development of Economy 14(4): 612-627. doi:10.3846/1392-8619.2008.14.612-627

Vaidogas, E. R.; Juocevicius, V. 2009. Assessment of structures subjected to accidental actions using crisp and uncertain fragility functions, Journal of Civil Engineering and Management 15(1): 95-104. doi:10.3846/1392-3730.2009.15.95-104

Weng, W.; Chen, T.; Yuan, H.; Fan, W. 2006. Cellular automaton simulation of pedestrian counter flow with different walk velocities, Physical Review E 74: 7. doi:10.1103/PhysRevE.74.036102

Yang, L.; Zhao, D.; Li, J.; Fang, T. 2005. Simulation of the kin behaviour in building occupant evacuation based on cellular automation, Building and Environment 40(3): 411416. doi:10.1016/j.buildenv.2004.08.005

Zavadskas, E. K.; Vaidogas, E. R. 2009. Multiattribute selection from alternative designs of infrastructure components for accidental situations, Computer-Aided Civil and Infrastructure Engineering 24(5): 346-358. doi:10.1111/j.1467-8667.2009.00593.x

Предтеченский, В. М.; Милинский, А. И. 1979. Проектирование зданий с учетом организации движения людских потоков [Predtechenskij,V. M.; Milinskij, A. I. Building Designing Taking into Account Movement of People Streams]. Москва: Стройиздат. $58 \mathrm{c}$.

Ройтман, М. Я. 1985. Противопожарное нормирование 6 строительстве [Roitman, M. J. Fire Norms in Building Industry]. Москва: Стройиздат. 590 с. 


\section{ŽMONIŲ EVAKUACIJOS IŠ PATALPU IR PASTATŲ PROJEKTAVIMAS}

\section{Papinigis, E. Geda, K. Lukošius}

\section{S a n tra k a}

Daugelyje civilinių pastatų ar inžinerinių statinių kyla gaisro rizikos pavojus. Žmonių evakuacijos laiko iš patalpos ar statinio analizė yra svarbi projektavimo dalis. Tačiau žmonių elgsenos gaisro sąlygomis analizè yra labai sudètinga. Ivairūs fizikiniai ir netgi psichologiniai veiksniai, darantys ịtaką saugiai žmonių evakuacijai iš statinių, turi būti ịvertinti. Išrasti analitiniai ir skaičiuojamieji metodai, skirti žmonių evakuacijai gaisro sąlygomis analizuoti. Deja, sudètingu skaičiavimų metodų taikymas žmonių evakuacijai nustatyti reikalauja pernelyg daug išteklių, todèl jų taikymas yra ribotas. Šiame straipsnyje pateikiamas žmonių evakuacijos skaičiavimo metodas, paremtas fizikinèmis žmonių srauto charakteristikomis (tankiu, intensyvumu, judejjimo greičiu), priklausomai nuo žmonių judejjimo būdo. Palyginti aprašyto ir sudètingojo žmonių evakuacijos skaičiavimo metodų, naudojant FDS+Evac programinę iranga, rezultatai.

Reikšminiai žodžiai: žmonių evakuacija, sauga, evakuacijos laikas, FDS+Evac.

Vytautas PAPINIGIS. Doctor, Associate Professor. Dept of Reinforced Concrete and Masonry Structures. Vilnius Gediminas Technical University (VGTU), Sauletekio al. 11, LT-10223 Vilnius, Lithuania.

Doctor (1982). Author of over 50 publications. Research interests: theory of reinforced concrete behaviour, composite structures, strengthening of structures.

Edgaras GEDA. Head of Standartization Division, State Fire Supervision Board, Fire and Rescue Department under the Ministry of the Interior of the Republic of Lithuania, Švitrigailos g. 18, LT-03223 Vilnius.

$\mathrm{PhD}$, Department of Bridges and Special Structures, Vilnius Gediminas Technical University, Sauletekio al. 11, LT-10223 Vilnius. Author of over 5 publications. Research interests: fire safety engineering, concrete structures behaviour in fire.

Kęstutis LUKOŠIUS. Doctor, Associate Professor. Dept of Labour and Fire safety. Vilnius Gediminas Technical University (VGTU), Saulètekio al. 11, LT-10223 Vilnius, Lithuania.

Doctor (2002). Author of over 10 publications. Research interests: fire safety engineering, heat conduction in structures, reaction to fire. 